\title{
STRUKTUR, DIKSI, DAN KONJUNGSI TEKS PROSEDUR KARYA SISWA KELAS VII SMP NEGERI 7 SIJUNJUNG
}

\section{PROPOSAL}

Tugas Mata Kuliah Metode Penelitian Pembelajaran Bahasa Indonesia yang Dibina oleh Prof. Dr. Syahrul R., M. Pd.

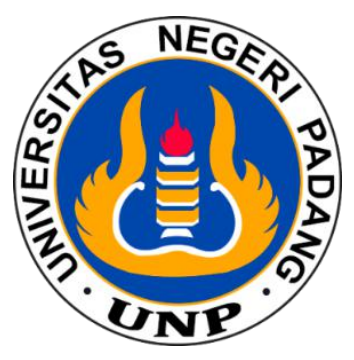

Refi Gustini

19016119

PROGRAM STUDI PENDIDIKAN BAHASA INDONESIA

JURUSAN BAHASA DAN SASTRA INDONESIA DAN DAERAH

FAKULTAS BAHASA DAN SENI

UNIVERSITAS NEGERI PADANG

2021 


\section{KATA PENGANTAR}

Assalamualaikum Warahmatullahi Wabarakatuh.

Alhamdulillah, puji syukur kita ucapkan atas kehadirat Allah SWT., berkat Rahmat dan Karunia-Nya penulis dapat menyelesaikan proposal yang berjudul "Struktur, Diksi, dan Konjungsi Teks Prosedur Karya Siswa Kelas VII SMP Negeri 7 Sijunjung" ini tepat pada waktunya. Shalawat serta salam semoga selalu tercurahkan kepada Baginda kita yakninya Nabi Muhammad SAW. yang kita nantikan syafaatnya di akhirat kelak.

Penulis mengucapkan terima kasih atas bantuan dari seluruh pihak yang telah membantu menyumbangkan materi maupun pikirannya dalam penyelesaian makalah ini, terutama kepada Bapak Prof. Dr. Syahrul R., M. Pd. selaku dosen pengampu Mata Kuliah Metode Penelitian Pembelajaran Bahasa Indonesia.

Penulis berharap, proposal ini dapat menambah wawasan dan pengetahuan pembaca mengenai "Struktur, Diksi, dan Konjungsi Teks Prosedur Karya Siswa Kelas VII SMP Negeri 7 Sijunjung". Karena keterbatasan pengetahuan maupun pengalaman, penulis menyadari masih banyak terdapat kekurangan dalam penulisan proposal ini. Oleh karena itu penulis sangat mengharapkan kritik dan saran dari pembaca demi kesempurnaan proposal ini.

Wassalamualaikum Warahmatullahi Wabarakatuh.

Sijunjung, 10 September 2021

Penulis 
KATA PENGANTAR ............................................................................

DAFTAR ISI ........................................................................................... ii

\section{BAB I PENDAHULUAN}

A. Latar Belakang Masalah ................................................................... 1

B. Fokus Masalah ........................................................................................ 4

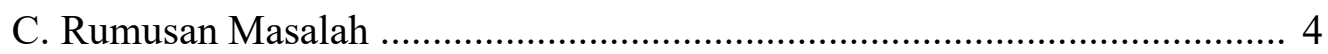

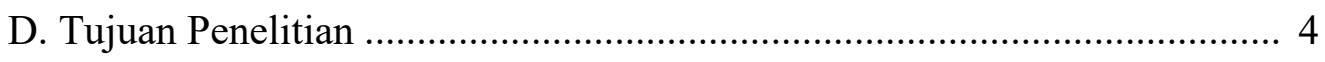

E. Manfaat Penelitian .......................................................................... 4

\section{BAB II KAJIAN PUSTAKA}

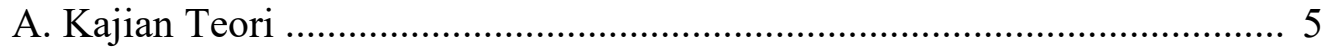

1. Konsep Dasar Teks .............................................................................. 5

2. Hakikat Teks Prosedur ....................................................................... 7

3. Struktur Teks Prosedur ........................................................................ 10

4. Kebahasaan Teks Prosedur .............................................................. 13

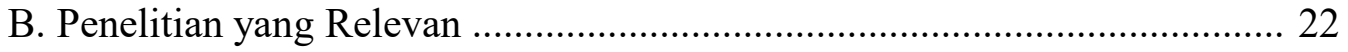

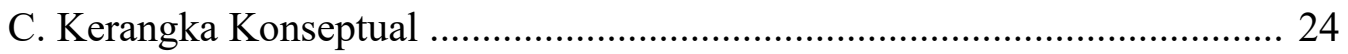

\section{BAB III METODOLOGI PENELITIAN}

A. Jenis dan Metode Penelitian ......................................................................... 25

B. Data dan Sumber Data ........................................................................... 25

C. Instrumen Penelitian ............................................................................... 26

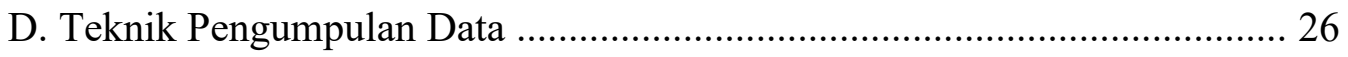

E. Teknik Pengabsahan Data .......................................................................... 26

F. Teknik Penganalisisan Data ................................................................. 27

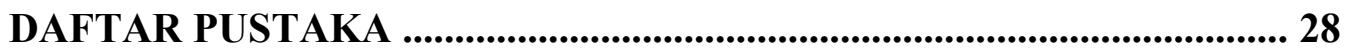




\section{BAB I}

PENDAHULUAN

\section{A. Latar Belakang Masalah}

Pembelajaran Bahasa Indonesia dalam Kurikulum 2013 adalah pembelajaran berbasis teks. Berkaitan dengan kurikulum 2013 tersebut, setiap siswa dituntut untuk bisa memahami dan memproduksi teks yang dipelajari sesuai dengan tujuan dan fungsinya dalam kehidupan sosial. Sejalan dengan pendapat Simanjuntak, Nurmina, Harris, E.T., dan Afnita (2018:250) bahwa kurikulum 2013 bertujuan mempersiapkan siswa memiliki kemampuan hidup sebagai pribadi dan warga negara yang kreatif, inovatif, efektif, serta mampu berkontribusi pada kehidupan bermasyarakat, berbangsa, dan bernegara. Dalam pembelajaran berbasis teks, bahasa Indonesia diajarkan bukan hanya tentang pengetahuan bahasa, melainkan teks yang mengemban fungsi untuk menjadi sumber aktualisasi dan penggunaan dalam konteks sosial budaya akademis. Sejalan dengan pendapat Ningsih, (2017:33) bahwa pembelajaran berbasis teks merupakan pembelajaran yang berorientasi pada kemampuan siswa untuk menyusun teks. Bagaimana peserta didik mampu mengonstruksikan pengetahuannya dan terampil menyusun serta mampu mengembangkan teks. Selain itu, pembelajaran Bahasa Indonesia berbasis teks dimaknai sebagai pembelajaran yang mengantarkan peserta didik untuk dapat berpikir sistematis, terkontrol, empiris, dan kritis (Agustina 2017:84). Teks merupakan satuan bahasa yang digunakan sebagai ungkapan suatu kegiatan sosial, baik secara lisan maupun tulis dengan struktur berpikir yang lengkap (Mahsun 2014:1). Untuk itu, siswa dituntut untuk terampil memproduksi teks melalui kegiatan menulis. Setiap teks memiliki tujuan dan fungsi sosial yang berbeda. Oleh karena itu, siswa harus mampu memahami semua jenis teks. Teks yang terdapat dalam Kurikulum 2013 diikat oleh struktur dan ciri kebahasaan. 1Hal yang sama diungkapkan oleh Atmazaki, Afnita, dan Farel (2017:58) bahwa bahasa Indonesia berbasis teks merupakan pembelajaran berdasarkan struktur dan kebahasaan teks, pembelajaran berdasarkan hal tersebut merupakan hal baru dalam pembelajaran bahasa Indonesia. 
Menulis teks prosedur merupakan salah satu materi ajar semester satu kelas VII pada kurikulum 2013. Dalam penelitian ini, peneliti memilih teks prosedur sebagai objek penelitian karena teks prosedur termasuk teks yang dipelajari siswa pada semester pertama kelas VII. Dalam pelaksanaannya, sebagian besar siswa masih bermasalah dalam menulis teks prosedur dengan tepat. Hal yang sama diungkapkan oleh Utami, dkk (2019:121) yang mengatakan bahwa salah satu bentuk tulisan yang bermasalah dikerjakan oleh siswa adalah teks prosedur karena siswa beranggapan bahwa keterampilan menulis teks prosedur sangat sulit. Hal senada juga dikemukakan oleh Azura (2014:4) ditemukan bahwa struktur dan kebahasaan dalam keterampilan menulis teks prosedur siswa masih bermasalah. Sejalan dengan itu, Ulfa (2019:470) mengungkapkan bahwa sebagian siswa belum terampil menulis teks prosedur dikarenakan siswa belum memahami teks prosedur secara menyeluruh. Kenyataan di lapangan juga menunjukkan bahwa dalam keterampilan menulis tek prosedur, siswa masih banyak mengalami kesulitan. Hal ini dibuktikan dengan penelitian yang dilakukan oleh Zurita, Thahar, dan Tamsin (2018) dan Mandasari, Atmazaki, dan Noveria (2018). Kedua penelitian tersebut mengungkapkan bahwa keterampilan siswa dalam menulis teks prosedur masih banyak mengalami kesulitan. Kesulitan tersebut di antaranya siswa belum mampu menulis struktur teks prosedur secara sistematis, penyajian isi teks prosedur tidak relevan dengan strukturnya, dan siswa kesulitan dalam menemukan ide untuk dijadikan topik dalam menulis. Selain itu, kurangnya penguasaan kosakata dan motivasi siswa dalam menulis.

Struktur teks mencerminkan struktur berpikir seseorang. Penguasaan jenis teks tertentu akan menghasilkan kemampuan berpikir sesuai dengan struktur teks yang dikuasai. Semakin banyak teks yang dikuasai, semakin banyak pula struktur berpikir yang dimiliki siswa. Dengan demikian siswa mampu berpikir kritis dalam menghadapi situasi yang berbeda di dalam konteks kehidupan sosialnya. Menurut Mustika, Nursaid, dan Noveria (2018:40) dalam penelitiannya, menyatakan bahwa struktur teks dalam masing-masing jenis teks memiliki perangkat-perangkat kebahasaan yang digunakan untuk mengekspresikan pikiran yang dikehendaki dalam tiap-tiap struktur teks. Selain struktur teks, aspek ciri kebahasaan juga sangat penting dalam penulisan sebuah teks, khususnya teks prosedur. Teks 
prosedur mempunyai enam unsur kebahasaan, yaitu diksi, konjungsi (kata hubung), numeralia (kata bilangan), kalimat imperatif (kalimat perintah), nomina (kata benda), dan verba (kata kerja). Unsur kebahasaan tersebut merupakan unsur pembentuk kalimat yang membentuk unsur struktur. Unsur struktur dirangkai sesuai ketentuan yang ada, sehingga terbentuk sebuah teks prosedur. Menurut Finoza (2010:80-97) diksi adalah satuan bentuk terkecil (dari kalimat) yang dapat berdiri sendiri dan mempunyai makna. Verba adalah kata yang menyatakan perbuatan atau tindakan, proses, dan keadaan yang bukan merupakan sifat atau kaulitas. Kata benda atau nomina adalah kata yang mengacu kepada sesuatu benda baik konkret maupun abstrak. Konjungsi adalah kata tugas yang berfungsi menghubungkan dua kata atau dua kalimat. Kalimat imperatif adalah kalimat perintah.

Berdasarkan pengamatan dari peneliti, dalam menulis teks prosedur siswa masih mengalami kesulitan. Hal itu dikarenakan siswa belum memahami teks prosedur secara menyeluruh. Guru bahasa Indonesia SMP Negeri 7 Sijunjung, Yetti Murni, S.Pd., juga mengungkapkan permasalahan tersebut pada saat wawancara pada 10 Agustus 2021. Dari wawancara tersebut, diperoleh laporan bahwa terdapat permasalahan lain yang ditemukan, dapat dilihat dari dua aspek yaitu: pertama, siswa belum mahir dalam membuat semua unsur strukutur teks prosedur, pada umumnya siswa hanya menggunakan 3 struktur teks prosedur dari 5 struktur yang ada. Kedua, dalam memproduksi teks masih ada penggunaan unsur kebahasaan teks prosedur yang belum tepat.

Berdasarkan permasalahan tersebut, maka penelitian tentang struktur, diksi, dan konjungsi teks prosedur karya siswa kelas VII SMP Negeri 7 Sijunjung penting untuk diteliti. Penelitian ini difokuskan pada struktur teks prosedur karya siswa kelas VII SMP Negeri 7 Sijunjung. Struktur teks prosedur tersebut antara lain judul, tujuan, alat atau bahan, langkah- langkah membuat, dan penutup. Teks prosedur mempunyai dua ciri kebahasaan yakni diksi (pilihan kata) dan konjungsi (kata hubung). 


\section{B. Fokus Masalah}

Berdasarkan permasalahan tersebut, maka penelitian tentang struktur, diksi, dan konjungsi teks prosedur karya siswa kelas VII SMP Negeri 7 Sijunjung penting untuk diteliti. Penelitian ini difokuskan pada struktur teks prosedur karya siswa kelas VII SMP Negeri 7 Sijunjung. Struktur teks prosedur tersebut antara lain judul, tujuan, alat atau bahan, langkah- langkah membuat, dan penutup. Teks prosedur mempunyai dua ciri kebahasaan yakni diksi (pilihan kata) dan konjungsi (kata hubung).

\section{Rumusan Masalah}

Berdasarkan fokus masalah tersebut, rumusan masalah dalam penelitian ini dirumuskan sebagai berikut. (1) bagaimana struktur teks prosedur siswa kelas VII SMP Negeri 7 Sijunjung? (2) bagaimana diksi (pilihan kata) teks prosedur yang ditulis siswa kelas VII SMP Negeri 7 Sijunjung? (3) bagaimana konjungsi (kata hubung) yang ditulis siswa kelas VII SMP Negeri 7 Sijunjung?

\section{Tujuan Penelitian}

Tujuan penelitian ini ada tiga. Pertama, mendeskripsikan struktur (judul, tujuan, bahan dan alat, langkah-langkah, penutup) yang ada pada teks prosedur siswa kelas VII SMP Negeri 7 Sijunjung. Kedua, mendeskripsikan diksi (pilihan kata) yang terdapat pada teks prosedur siswa kelas VII SMP Negeri 7 Sijunjung. Ketiga, mendeskripsikan konjungsi (kata hubung) yang terdapat pada teks prosedur siswa kelas VII SMP Negeri 7 Sijunjung.

\section{E. Manfaat Penelitian}

Penelitian ini diharapkan bermanfaat baik secara teoretis maupun praktis. Secara teoretis, penelitian diharapkan bermanfaat dalam perkembangan ilmu kebahasaan, terutama dalam kajian teks prosedur. Secara praktis, penelitian ini diharapkan bermanfaat bagi pihak-pihak berikut. Pertama, bagi guru Bahasa Indonesia di SMP Negeri 7 Sijunjung sebagai bahan masukan dalam pelaksanaan pembelajaran. Kedua, bagi siswa kelas VII SMP Negeri 7 Sijunjung agar kedepannya bisa membuat teks prosedur dengan benar. 


\section{BAB II}

\section{KAJIAN PUSTAKA}

\section{A. Kajian Teori}

Berdasarkan permasalahan penelitian, landasan teori yang diuraikan pada bab ini secara garis besar ada lima yaitu, (1) konsep dasar teks, (2) hakikat teks prosedur, (3) struktur teks prosedur, (4) kebahasaan teks prosedur, dan (5) contoh teks prosedur.

\section{Konsep Dasar Teks}

\section{a. Pengertian Teks}

Kridalaksana (2008:238) menyatakan bahwa teks adalah satuan bahasa terlengkap yang bersifat abstrak. Dalam bidang wacana, teks adalah deretan kalimat, kata, dan sebagainya yang membentuk sebuah ujaran. Selain itu, teks merupakan bentuk bahasa tertulis atau naskah, atau ujaran yang dihasilkan dalam interaksi manusia. Teks merupakan satuan bahasa terlengkap karena mencakup kalimat, kata, dan sebagainya. Unsur pembangun teks tersebut tersusun secara padu dengan struktur dan kebahasaan yang sesuai dengan kaidah bahasa yang baik dan benar.

Haliday dan Ruqaiya (dalam Mahsun, 2014:1) menyebutkan bahwa teks merupakan jalan menuju pemahaman tentang bahasa. Teks merupakan bahasa yang berfungsi atau bahasa yang sedang melaksanakan tugas tertentu dalam konteks situasi. Dengan demikian, teks merupakan ungkapan pernyataan sesuatu kegiatan sosial yang bersifat verbal.

Menurut Barthes (dalam Sobur 2012:52) teks adalah sebuah objek kenikmatan. Sebuah kenikmatan dalam pembacaan sebuah teks adalah kesenangan kala menyusuri halaman demi halaman objek yang dibaca. Kenikmatan pembacaan itu bersifat individual.

Selanjutnya, menurut Mahsun (2014), teks terbagi atas dua jenis berdasarkan genrenya, yaitu genre sastra dan genre non sastra. Teks genre sastra berupa teks genre cerita, sedangkan non sastra berupa teks faktual dan teks tanggapan. Hal serupa diungkapkan oleh Anderson (dalam Priyatni, 2014:66) 
yang menyebutkan bahwa teks dikelompokkan atas dua kategori (genre), yaitu genre sastra dan genre faktual. Genre sastra berupa teks naratif, puitik, dan dramatik, sedangkan genre faktual berupa teks eksplanasi, eksposisi, prosedur, dan lain-lain.

Dalam teori bahasa, apa yang dinamakan teks tak lebih dari himpunan huruf yang membentuk kata dan kalimat yang dirangkai dengan sistem tanda yang disepakati oleh masyarakat, sehingga sebuah teks ketika dibaca mengungkapkan makna yang dikandungnya. Berdasarkan pendapat-pendapat tersebut dapat disimpulkan bahwa teks pada dasarnya tidak dapat dilepaskan sama sekali dari teks lain. Teks merupakan dunia semesta ini, bukan hanya teks tertulis atau teks lisan, adat istiadat, kebudayaan, film, dan drama juga disebut dengan teks.

\section{b. Fungsi Komunikasi Teks}

Sebagai sarana komunikasi, bahasa menjadi pintu masuk untuk memahami dan sekaligus mengembangkan ilmu pengetahuan, sedangkan sebagai lambang identitas atau jati diri bahasa menjadi penanda dan sekaligus pembeda suatu komunitas dengan komunitas lainnya. Sebagai sarana kerja sama maksudnya melalui bahasa, manusia menyampaikan pikiran termasuk perasaannya. Dengan bahasa kita dapat memahami pikiran-pikiran penutur baik pikiran tentang dirinya maupun pikiran tentang penutur bahsa lain. Fungsi komunikasi teks prosedur pada masyarakat atau pembaca adalah untuk mengajak kerja sama antara penulis dengan pembaca yang memberi petunjuk cara melakukan sesuatu melalui serangkaian tindakan atau kegiatan.

\section{c. Fungsi Lokasi Sosial Teks}

Setiap pemakaian bahasa selalu memiliki tujuan. Tujuan yang dimaksudkan di sini tentu tujuan sosial, karena bahasa tidak lain merupakan sarana untuk melaksanakan proses sosial. Bahasa yang digunakan dengan tujuan sosial tertentu itulah yang melahirkan teks. Selanjutnya, proses sosial yang berlangsung selalu memiliki muatan nilai-nilai atau norma-norma kultural. Artinya, nilai-nilai atau norma-norma kultural akan direalisasikan dalam suatu proses sosial. Setiap teks merupakan wujud dari proses sosial yang berlangsung 
dalam konteks situasi tertentu memiliki muatan nilai-nilai atau norma-norma kultural. Sejalan dengan pandangan ini, Persons (1977) dalam bukunya Social System and The Evaluation of Action Theory menyatakan bahwa sistem budaya (nilai, norma) akan mengontrol sistem tingkah laku manusia melalui sistem sosial. Begitu juga dengan teks prosedur yang terdapat pada lokasi sosial kehidupan sehari-hari.

Tujuan sosial dari teks prosedur adalah mengarahkan atau mengajarkan tentang langkah-langkah yang telah ditentukan. Dengan demikian teks ini lebih menekankan bagaimana melakukan sesuatu yang dapat berupa salah satunya percobaan atau pengamatan.

\section{Hakikat Teks Prosedur}

\section{a. Pengertian Teks Prosedur}

Dalam Kamus Besar Bahasa Indonesia (Depdiknas, 2008:106) prosedur adalah tahap kegiatan untuk menyelesaikan suatu aktivitas, metode langkah demi langkah secara pasti dalam memecahkan suatu masalah. Kata prosedur berkategori nomina, prosedur berarti tahapan kegiatan untuk menyelesaikan suatu aktivitas. Kata prosedur juga dapat diartikan metode, langkah demi langkah secara pasti dalam memecahkan suatu masalah. Prosedur ialah suatu rangkaian tugas saling berhubungan yang merupakan urutan-urutan menurut waktu dan tata cara tertentu untuk melaksanakan suatu kegiatan atau pekerjaan yang dilaksanakan berulang-ulang.

Teks prosedur merupakan teks yang berisi tujuan dan langkah-langkah yang harus diikuti agar suatu pekerjaan dapat dilakukan (Kemendikbud, 2014:84). Di dalam teks prosedur diuraikan bagaimana sesuatu dikerjakan melalui serangkaian langkah atau tindakan. Teks prosedur merupakan salah satu jenis teks nonsastra. Jenis teks ini berisi langkah-langkah atau tahap-tahap yang harus ditempuh untuk mencapai tujuan.

Menurut Mulyadi (2014:89), teks prosedur merupakan jenis teks yang berisi langkah-langkah yang harus ditempuh untuk mencapai tujuan yang diinginkan. Langkah-langkah itu harus sistematis dan tidak dapat balik-balik. Menurut Perdana, dkk. (2014:36) teks prosedur adalah langkah-langkah atau 
tahapan yang harus ditempuh untuk mencapai tujuan. Teks tersebut ditata dengan struktur tujuan dan langkah-langkah. Yang dimaksud dengan tujuan ialah hasil akhir yang akan dicapai. Langkah-langkah adalah cara-cara yang akan ditempu agar tujuab itu tercapai. Pada teks prosedur, langkah-langkah itu merupakan urutan yang biasanya tidak dapat diubah urutannya. Langkah awal menjadi penentu langkah berikutnya.

Feez dan Joyce (dalam Gafur dan Milaningrum, 2015:56) menjelaskan bahwa teks prosedur menunjukkan bagaimana melaksanakan tindakan dalam urutan tertentu. Menurut Nurlailatul Asadah, dkk. (2016:3) teks prosedur merupakan suatu langkah-langkah dan tujuan yang harus diikuti agar sesuatu pekerjaan dapat dilakukan. Teks prosedur memiliki manfaat yang besar dalam kehidupan. Teks prosedur dapat membantu mengetahui cara-cara melakukan aktivitas tertentu dan kebiasaan hidup yang benar. Selain itu, membantu dalam menggunakan alat-alat dengan benar tanpa membahayakan diri dan tanpa merusak alat itu sendiri. Untuk mencapai tujuan yang tepat, teks prosedur disusun sesuai dengan urutan yang benar karena langkah-langkah dalam menyusun teks prosedur tidak dapat dibalik-balik untuk mencapai tujuan tersebut.

Berdasarkan pendapat di atas, dapat disimpulkan bahwa teks prosedur merupakan suatu teks yang berisi tujuan dan langkah-langkah kegiatan untuk menyelesaikan suatu pekerjaan dengan urutan yang tepat.

\section{b. Ciri-ciri Teks Prosedur}

Ciri teks prosedur dari segi isinya ada tiga: (1) panduan langkah-langkah uang harus dilakukan, (2) aturan atau batasan dalam hal bahan atau kegiatan dalam melakukan kegiatan, (3) isi kegiatan yang dilakukan secara runtut (kalau tidak disebut tips). Selain untuk pembelajaran, teks prosedur ini bisa kita temukan di majalah, koran, dan buku bahan masakan.

\section{c. Fungsi Teks Prosedur}

Fungsi teks prosedur adalah memberikan petunjuk tentang cara melakukan sesuatu melalui serangkaian tindakan atau langkah atau menunjukkan beberapa tahapan sesuai dengan langkah-langkah yang telah ditentukan (Kemendikbud, 
2013:84). Teks prosedur berfungsi untuk memberikan informasi berupa petunjuk kepada pembacanya untuk menyelesaikan suatu aktivitas dengan tepat. Melalui informasi yang disediakan tersebut, pembaca akan mengetahui langkah-langkah pelaksanaan kegiatan yang akan dilakukannya, sehingga kegiatan dapat terbantu dan terlaksana dengan baik. Selain itu, teks prosedur juga berguna dalam kehidupan sehari-hari. Uraian dalam teks prosedur berfungsi untuk memudahkan terlaksananya suatu kegiatan.

\section{d. Jenis Teks Prosedur}

Mulyadi (2014:105-108) mengatakan bahwa teks prosedur terbagi atas dua jenis, yaitu teks prosedur melakukan sesuatu dan teks prosedur membuat sesuatu.

\section{1) Teks Prosedur Melakukan Sesuatu}

Teks prosedur melakukan sesuatu merupakan jenis teks prosedur yang sengaja dibuat untuk petunjuk dalam melakukan sesuatu pekerjaan. Dari segi struktur, jenis teks prosedur ini hanya memiliki dua struktur, yaitu tujuan dan langkah-langkah yang dilakukan. Aspek kebahasaan jenis teks ini lebih banyak menggunakan kalimat perintah. Misalnya cara mengatasi rasa malas.

\section{2) Teks Prosedur Membuat Sesuatu}

Jenis teks prosedur membuat sesuatu mempunyai tiga struktur, yaitu tujuan yang ingin dicapai, bahan yang digunakan, serta langkah-langkah pembuatannya. Ditinjau dari segi kebahasaan, teks ini juga terdapat kalimat perintah dan kata kerja imperatif, yakni kata kerja yang bermakna perintah. Selain itu, dalam jenis teks ini terdapat konjungsi pengurutan. Misalnya, cara membuat es krim coklat.

\section{e. Langkah-langkah Menulis Teks Prosedur}

Menurut Mulyadi (2014:94), ada beberapa langkah dalam menyusun teks prosedur, yaitu pertama, memilih dan menentukan topik. Pemilihan topik yang tepat dapat menarik perhatian pembaca untuk mengetahui lebih dalam tentang apa yang dijabarkan dalam tulisan tersebut. Dalam menulis, pemilihan topik sangatlah penting dan dapat menentukan hasil dari tulisan. Beberapa syarat yang harus diperhatikan dalam menentukan topik suatu karya tulis sebagai berikut. (a) topik 
harus menarik perhatian penulis, (b) topik harus dipahami atau diketahui penulis, (c) jangan terlalu baru, teknis, dan kontroversial, dan (d) bermanfaat dan jangan terlalu luas.

Setiap penulis harus betul-betul yakin bahwa topik yang dipilihnya cukup sempit dan terbatas untuk digarap sehingga tulisan bisa fokus dan tepat sasaran. Berikut ini adalah cara membatasi sebuah topik. (a) tetapkanlah topik dalam kedudukan sentral, (b) ajukan pertanyaan tentang topik, (c) tetapkanlah mana subtopik yang akan dipilih, (d) ajukanlah pertanyaan tentang subtopik agar lebih rinci, (e) lakukan proses di atas secara terus menerus hingga mendapatkan sebuah tema.

Kedua, menentukan tema. Penentuan tema dilakukan untuk membatasi topik tulisan. Tema merupakan hal-hal khusus (spesifikasi) dari topik yang telah ditentukan. Ketiga, menulis pengantar yang menjelaskan tujuan atau menetapkan tujuan penulisan. Penetapan tujuan penulisan akan membantu penulis dalam mengembangkan tulisannya dan memberikan arah kepada penulis terhadap apa yang akan ditulis. Keempat, mengumpulkan bahan tulisan.

\section{Struktur Teks Prosedur}

Teks prosedur dibangun oleh struktur yang menjadikannya sebuah teks yang baik. Struktur teks prosedur terdiri atas judul, tujuan, bahan/alat, langkahlangkah, dan penutup (Harsiati, Agus, dan E. Kosasih, 2016:98-103). Judul, bagian ini berisi pemberitahuan tentang kegiatan yang akan dilakukan. Tujuan, bagian ini berisi tujuan kegiatan, pembaca teks segera mengetahui tujuan kegiatan pada bagian awal teks. Bahan, dan alat, berisi bahan atau perlengkapan yang tersedia. Langkah-langkah harus dilakukan secara urut agar tujuan dapat tercapai. Penutup berisi bagian lain penekanan pada keuntungan dan ucapan selamat untuk pembaca. Kelima bagian itu menjadi bangunan teks prosedur. Namun, bagian bahan/alat menjadi struktur utama dalam teks prosedur karena bahan dan alat juga disebutkan dalam bagian langkah-langkah. Langkah-langkah ini harus sesuai dengan uraian pertama sampai uraian akhir dan tidak boleh dilakukan secara terbalikatau diacak. Pada bagian penutup berupa kata ucapan selamat atau keuntungan bila melakukan prosedur ini. Dengan demikian struktur teks prosedur 
adalah judul, tujuan, alat dan bahan, langkah-langkah, dan penutup (Harsiati, Agus, dan E. Kosasih, 2016:101).

\section{a. Judul}

Menurut Harsiati, Agus, dan E. Kosasih, (2016:99) Judul merupakan pengantar umum sebagai penanda apa yang akan dibuat atau yang akan dilakukan. Judul dalam teks prosedur sudah merangkup dalam tujuan. Menurut Aminuddin, judul adalah sebuah ide yang mendasari sebuah pembahasan atau sebuah cerita, dan judul itu akan menjadi sebuah tolak ukur akan pembahasan yang ditulis oleh seorang penulis. Jadi dapat disimpulkan bahwa judul ialah pandangan hidup atau perasaan mengenai kahidupan dan rangkaian nilai-nilai tertentu yang membentuk dan menjadi sebuah dasar dari gagasan utama seorang penulis.

\section{b. Tujuan}

Harsiati, Agus, dan E. Kosasih, (2016:101) tujuan teks prosedur menjelaskan kegiatan yang harus dilakukan agar pembaca secara tepat dan akurat mengikuti sebuah proses membuat sesuatu, melakukan sesuatu pekerjaan, atau menggunakan suatu alat. Pada bagian tujuan berisi tujuan kegiatan. Pembaca teks dapat mengetahui tujuan kegiatan pada bagian awal teks prosedur. Tujuan merupakan pengantar topik yang akan dijelaskan dalam teks. Pada contoh teks prosedur yang berjudul "cara membuat bubur manado", pendahuluan yang dimaksud berupa gambaran umum dari bubur manado dan manfaat bagi yang mengkonsumsi, (paragraf 1).

\section{c. Alat dan Bahan}

Teks prosedur sebagai cara membuat sesuatu diperlukan alat dan bahan. Misalnya, resep makanan, membuat hiasan, atau membuat yang lain lain. Alat dan bahan dirinci sampai ukuran yang akurat karena untuk menghasilkan produk yang baik. Pada bagian alat dan bahan berisi bahan-bahan atau perlengkapan untuk mencapai tujuan (Harsiati, Agus, dan E. Kosasih, 2016:102). 


\section{d. Langkah-langkah}

Langkah-langkah teks prosedur merupakan inti dari teks prosedur. Langkah-langkah berisi tahap-tahap kegiatan. Pada bagian langkah-langkah berisi tahapan untuk mencapai tujuan kegiatan berdasarkan berbagai bahan atau perlengkapan yang tersedia. Langkah-langkah harus dilakukan secara terurut agar tujuan dapat tercapai. Langkah-langkah berupa perincian yang disarankan kepada pembaca terkait dengan topik yang ditentukan (Harsiati, Agus, dan E. Kosasih, 2016:102).

\section{e. Penutup}

Cara membuat penutup teks prosedur ialah merujuk kembali ke hal-hal pokok yang disebutkan dalam pendahuluan dan ulang kembali dengan kata-kata yang lain (sinonim) atau ucapan selamat atau memotivasi orang untuk melakukan. Ucapan selamat menikmati keindahan, kenyamanan, kelezatan, hasil kegiatan yang dilakukan. Bagian penutup merujuk pada bagian pendahuluan atau keuntungan bila melakukan prosedur ini, penutup sering disebut penegasan ulang berupa harapan atau manfaat apabila petunjuk-petunjuk itu dijalankan dengan baik, (Kemendikbud, 2014:38). Untuk lebih jelas mengenai struktur teks prosedur, perhatikan bagan berikut.

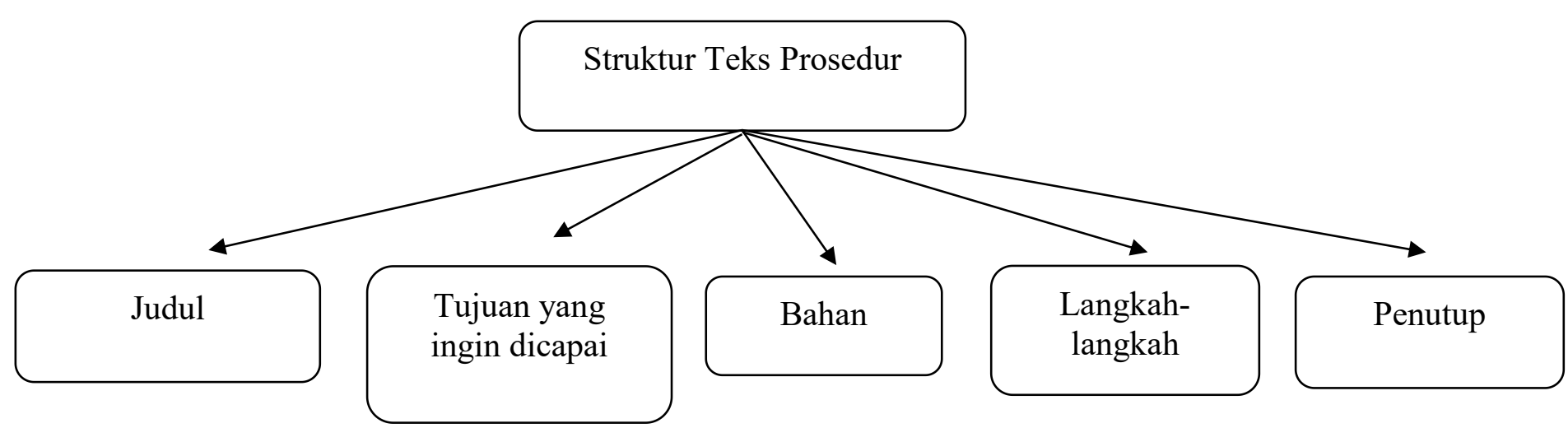

Gambar 2

Struktur Teks Prosedur 


\section{Unsur Kebahasaan dalam Teks Prosedur}

Pada dasarnya ciri kebahasaan dari teks prosedur adalah sebagai berikut. Pertama, menggunakan konjungsi. Kedua, menggunakan kata bilangan (numeralia). Ketiga, banyak menggunakan kalimat perintah (kalimat imperatif). Keempat, menggunakan nomina. Kelima, menggunakan verba (kata kerja). Keenam, menggunakan diksi (pilihan kata). Berikut dijelaskan satu persatu unsur kebahasaan teks prosedur. Namun dalam penelitian ini, unsur kebahasaan yang diteliti oleh peneliti hanya tiga yaitu penggunaan diksi, konjungsi, dan kalimat perintah.

\section{a. Menggunakan Konjungsi}

Konjungsi merupakan kata-kata yang digunakan untuk menghubungkan kata dengan kata, klausa dengan klausa, atau kalimat dengan kalimat. Konjungsi dalam bahasa Indonesia sangat beragam, diantaranya konjungsi penjumlahan (dan, sreta, dengan), pemilihan (atau), pertentangan (tetapi, namun, sedangkan, sebaliknya), penegasan (bahkan, apalagi, lagi, pula, hanya, itupun, begitu juga), pembatasan (kecuali), pengurutan (sesudah, sebelum, lalu, mula-mula, kemudian, selanjutnya, setelah itu), dan penyimpulan jadi, oleh karena itu, dengan demikian). Menurut Menurut Finoza (2010:97) konjungsi adalah kata tugas yang berfungsi menghubungkan dua kata atau dua kalimat.

Menurut Rahardi (2009:65) konjungsi atau kata penghubung adalah kata yang berfungsi untuk menghubungkan entitas-entitas kebahasaan di dalam sebuah kalimat. Konjungsi juga digunakan untuk menghubungkan kalimat satu dengan kalimat laindalam satu paragraf yang utuh. Selanjutnya, Chaer (2009:81-82) menyatakan bahwa konjungsi adalah kategori yang menghubungkan kata dengan kata, klausa dengan klausa, kalimat dengan kalimat, dan paragraf dengan paragraf. Chaer (2011:103) membedakan konjungsi berdasarkan cara penghubungnya menjadi tiga, yaitu konjungsi subordinatif, konjungsi koordinatif, dan konjungsi korelatif. 


\section{1) Konjungsi Subordinatif}

Chaer (2011:115) menyatakan bahwa konjungsi subordinatif adalah konjungsi yang menghubungkan dua satuan bahasa secara tidak sederajat. Artinya, bahasa yang satu punya kedudukan yang lebih tinggi dari satuan bahasa yang lain. Konjungsi subordinatif biasanya digunakan dalam kalimat majemuk bertingkat. Makna hubungan yang dapat dijelaskan oleh konjungsi subordinatif ini adalah konjungsi yang menyatakan (1)syarat, (2) sebab, (3) tujuan, (4) kesewaktuan, (5) penyuguhan, (6) perbandingan, (7) batas akhir, (8) pengandaian. Setiap konjungsi mempunyai anggota atau kata-kata yang menandai konjungsi tersebut. Pertama, yang menyatakan sebab ditandai dengan adanya kata karena, sebab, gara-gara, dan lantaran. Kedua, konjungsi yang menyatakan syarat ditandai dengan adanya kata kalau, jika, jikalau, bila, apabila, apalagi, bilamana, dan asal. Ketiga, konjungsi yang menyatakan tujuan ditandai dengan adanya kata untuk, agar, supaya, guna, dan demi. Keempat, konjungsi yang menyatakan kesewaktuan ditandai dengan kata ketika, waktu, saat, tatkala, selagi sebelum, setelah, sejenak, dan semenjak.

Kelima, konjungsi yang menyatakan penyuguhan ditandai dengan adanya kata meskipun, walaupun, sungguhpun, biarpun, dan kendatipun. Keenam, konjungsi yang menyatakan perbandingan dimulai dengan adanya kata-kata seperti, sebagai, bagai, laksana, dan seumpama. Ketujuh, konjungsi yang menyatakan batas akhir ditandai dengan adanya kata-kata sampai, hingga, dan sehingga. Kedelapan, konjungsi yang menyatakan pengandaian ditandai dengan adanya kata-kata andaikata, seandainya, dan andaikan.

Contoh konjungsi subordinatif

Mengosumsi sup buah sangat baik karena mengandung banyak serat yang berasal dari buah-buahan.

Buatlah kuah sup buah dengan mencampurkan air, susu kental manis, dalam tempat terpisah, aduk hingga rata.

\section{2) Konjungsi Koordinatif}

Chaer (2011:115) menyatakan bahwa konjungsi koordinatif adalah konjungsi yang menghubungkan dua satuan bahasa (kata, frase, klausa, dan 
kalimat) dalam kedudukan yang setara. Artinya, kedudukan dua kalimat yang dihubungkan tersebut sederajat, tidak ada yang lebih tinggi dan tidak ada yang lebih rendah. Makna hubungan yang dapat dijelaskan oleh konjungsi koordinatif ini adalah (1) penambahan, (2) pemilihan, (3) pertentangan, (4) penegasan, (5) penyamaan, (6 pengurutan atau urutan kejadian, (7) pembetulan, dan (8) pembatasan.

Konjungsi koordinatif memiliki anggota atau kata-kata yang menandai masing-masing jenis konjungsi koordinatif tersebut. Pertama, konjungsi koordinatif yang menyatakan penambahan ditandai dengan adanya kata dan dan serta. Kedua, konjungsi koordinatif yang menyatakan pemilihan ditandai dengan adanya kata atau. Ketiga, konjungsi koordinatif pertentangan ditandai dengan adanya kata-kata tetapi, namun, sedangkan, dan sebaliknya. Keempat, konjungsi koordinatif yang menyatakan penegasan atau penguatan ditandai dengan adanya kata bahkan, lagipula, dan apalagi.

Kelima, konjungsi yang koordinatif yang menyatakan penyamaan ditandai dengan adanya kata ialah, adalah, yaitu, dan yakni. Keenam, konjungsi koordinatif yang menyatakan urutan kejadian ditandai dengan adanya kata-kata lalu, kemudian, dan selanjutnya. Ketujuh, konjungsi koordinarif yang menyatakan pembetulan ditandai dengan adanya kata melainkan. Kedelapan, konjungsi koordinatif yang menyatakan pembatasan ditandai dengan adanya kata kecuali, dan hanya.

\section{Contoh konjungsi koordinatif}

Sup buah adalah salah satu jenis yang digemari semua kalangan umur.

Jenis makanan satu ini sangat enak dinikmati, apalagi dikonsumsi ketika dalam kondisi gerah atau panas.

\section{3) Konjungsi Korelatif}

Chaer (2011:124) menyatakan bahwa konjungsi korelatif adalah konjungsi yang menghubungkan dua buah kata, dua buah frase, atau dua klausa yang memiliki status sama. Anggota konjungsi korelatif ini adalah antara ... dan, baik ... maupun, entah tidak hanya ... entah, jangankan ... pun, tidak hanya ... tetapi juga, bukanhanya ... melainkan juga ..., demikian ... sehingga, dan sedemikian rupa ... 
sehingga.

Contoh konjungsi korelatif

Sup buah tidak hanya memberikan kesegaran, tetapi juga memiliki banyak manfaat untuk kesehatan tubuh kita.

\section{b. Menggunakan Kata Bilangan (Numeralia)}

Kridalaksana (1990:81) menjelaskan numeralia terdiri atas tiga kategori yaitu (1) yang dapat mendampingi nomina dalam kontruksi sintaksis, (2) mempunyai potensi untuk mendampingi numeralia lain, dan (3) tidak dapat bergabung dengan kata 'tidak' atau kata "sangat'. Numeralia dapat digolongkan menjadi numeralia takrif dan numeralia tak takrif. Numeralia takrif adalah numeralia yang menyatakan jumlah yang tentu, misalnya keenam, berlima, dan perempatan. Numeralia tak takrif adalah numeralia yang menyakan jumlah tan tentu, misalnya beberapa, sekalipun, semua, dan segenap. Berdasarkan pendapat tersebut, dapat disimpulkan bahwa kata bilangan atau numeralia adalah kata yang menyatakan jumlah dan urutan sesuatu atau menunjuk urutannya dalam sebuah deretan.

Menurut Ramlan (1991:42) numeralia disebut dengan kata bilangan yang mempunyai pengertian frase yang diperoleh dari sejumlah kata yang dapat diikuti kata orang, ekor, buah, helai, kodi, meter, dan sebagainya, serta yang dapat menyatakan jumlah dan urutan. Kata bilangan yang menyatakan jumlah misalnya, satu, dua, tiga puluh, beberapa. Kata bilangan yang menyatakan urutan misalnya, kedua, ketiga, ketiga belas, dan seterusnya. Kata bilangan atau numeralia merupakan kata yang menunjukkan bilangan atau kuantitas urutan dalam melakukan suatu hal (Kemendikbud, 2014:91).

Contoh kata bilangan dalam kalimat berikut.

Masak tepung ketan dan cairan santan selama 30 menit.

Potong kertas berwarna lebar $2,5 \mathrm{~cm}$ dan panjang $30 \mathrm{~cm}$ 


\section{c. Menggunakan Kalimat Imperatif dan Kalimat Deklaratif}

Kalimat imperatif disebut juga kalimat perintah. Kalimat imperative berfungsi untuk meminta atau melarang seseorang untuk melakukan sesuatu. Dalam teks prosedur, kita harus mengenali kalimat-kalimat perintah. Berikut ini adalah contoh kalimat imperatif.

1) Masukkan tepung terigu dan susu bubuk sedikit demi sedikit.

2) Aduk adonan ke loyang mini

3) Biarkan dingin, keluarkan kue dari loyang siram dengan selai blueberry secukupnya.

Kalimat deklaratif disebut juga kalimat pernyataan. Kalimat seperti itu berfungsi memberikan informasi atau berita tentang sesuatu. Kalimat deklaratif bermanfaat untuk menyusun teks prosedur pada bagian pengantar. Bagian pengantar sangat penting karena membuka isi teks, mencantumkan tujuan, dan menjelaskan bagian untuk menuju langkah-langkah. Berikut adalah contoh kalimat deklaratif.

1) Sup buah adalah makanan sehat yang digemari semua kalangan.

2) Pembuatan sup buah memiliki tujuan, diantaranya untuk meningkatkan daya tarik seseorang dalam mengonsumsi buah, menyehatkan, dan lainlain.

\section{d. Menggunakan Nomina dan Partisipan}

Nomina adalah kata yang mengacu pada orang, benda, atau hal-hal yang bersifat abstrak/konsep, misalnya kursi, bangunan, dan keputusan. Partisipan dalam teks prosedur biasanya manusia secara umum, seperti pengendara, anda, kita, disesuaikan dengan konteks kalimat. Sapaan dimaksudkan sebagai siapa saja yang ditargetkan oleh teks tersebut. Akan tetapi apabila teks prosedur itu disampaikan langsung secara lisan kepada mitra bicara, seperti anda atau kamu, yang dimaksud adalah orang yang diajak bicara itu.

Contoh penggunaan nomina dalam kalimat berikut.

Kita juga bebas untuk menentukan dingin dan tidaknya sup buah tersebut.

Kemas pada kardus kecil. 


\section{e. Menggunakan Verba (Kata Kerja)}

Verba atau kata kerja adalah kata yang menunjukkan aksi, peristiwa, keadaan, misalnya menulis, melihat, dan menyaksikan. Kata kerja dalam teks prosedur biasanya berupa verba tingkah laku (verba yang mengacu pada ungkapan verbal) atau verba material (verba yang mengacu pada tindakan fisik). Contoh verba tingkah laku yaitu menerima, menolak, dan sebagainya. Contoh verba material yaitu menulis, membaca, dan menyetir.

Chaer, (2011:100) menyatakan bahwa verba (kata kerja) dibedakan menjadi empat macam secara semantis yaitu Pertama, kata kerja yang menyatakan tindakan atau perbuatan. Misalnya kata membangun, makan, menendang, berlari, dan pergi. Kedua, kata kerja yang menyatakan pengalaman batin, menyatakan sikap, emosi, atau perasaan. Misalnya kata bosan, tahu, mengerti, sadar, takut, dan bangga. Ketiga, kata kerja yang menyatakan proses atau perubahan dari suatu keadaan kepada keadaan lain. Misalnya kata menguning, mencair, mendidih, tenggelam, terbit, dan membulat. Keempat, kata kerja yang menyatakan keadaan lahiriah sesuatu. Misalnya kata kosong, bergetar, menggigil, terbuka, dan berbekas.

Contoh verba dalam kalimat berikut.

Aduk adonan sampai mengental

Letakkan monitor sejajar dengan mata.

\section{f. Menggunakan Diksi (Pilihan Kata)}

Diksi artinya pilihan kata. Harus disadari bahwa kata adalah alat untuk menyalurkan gagasan (Thahar, 2008:16). Keraf dalam Thahar, 2008:16) menyatakan bahwa kata merupakan satu unit dalam bahasa yang memiliki stabilitas internal dan stabilitas posisional. Maksud dari stabilitas posisional adalah bahwa sebuah kata dapat berganti posisi dalam sebuah kalimat dengan menglami perubahan morfologis. Misalnya, kata mati dalam kalimat Tiba-tiba lampu mati berada pada posisi dengan maknanya dalam kalimat la menangisi kematian ibunya.

Diksi adalah ikhwal ketepatan pemilihan kata atau satuan leksikal untuk mengungkapkan gagasan dan kesesuaian kata atau satuan leksikal itu dengan 
konteks pemakaiannya. Kata yang tepat adalah kata yang dapat menimbulkan gagasan-gagasan yang tepat pada imajinasi pendengar atau pembaca seperti yang dipikirkan atau dirasakan pembicara atau penulis (Keraf, dalam Ngusman, 2010:119).

Marahimin, (2010:36) mengatakan bahwa diksi yang baik sebenarnya dapat menghasilkan gaya bahasa yang kuat. Ada banyak kata yang mengandung implikasi. Perkataan "putih' misalnya, dalam konteks tertentu dapat menyiratkan kesucian, dalam konteks lain dapat pula berarti takut atau takluk. Ketepatan makna diksi yang dipakai hendaklah sesuai dengan konteks. Kadang-kadang kita perlu mengambil kata-kata populer jika memamng pas dengan konteks. Putrayasa, (2010:7) menyatakan bahwa untuk menyusun kalimat efektif, hendaknya dipilih kata yang tepat, ialah yang memenuhi isoformisme. Isoformisme ialah kesamaan makna karena kesamaan pengalaman masa lalu atau adanya struktur kognitif.

Manaf (dalam Ngusman, 2010:119) menjelaskan bahwa ketepatan pemilihan kata paling sedikit dapat diukur berdasarkan tiga kriteria, yaitu (1) tepat konsep, (2) tepat nilai rasa, (3) tepat konteks pemakaian. Kata yang tepat konsep adalah kata yang dapat mengungkapkan pengertian suatu objek secara tepat. Contoh untuk meyakinkan pembeli, perusahaan elektronik itu memberikan garasi kepada pembeli. Kalimat itu tidak efektif karena mengandung pilihan kata yang tidak tepat konsep, yaitu garasi. Garasi memiliki makna "tempat menyimpan mobil” sehingga kata garasi itu tidak sesuai dengan konteks kalimat itu. Kalimat itu dapat diperbaiki dengan mengganti kata garasi menjadi garansi sehinggan kalimat itu bisa meyakinkan pembeli, perusahaan elektronik itu memberikan garansi kepada pembeli.

Kata yang tepat nilai rasa adalah kata yang dapat mengungkapkan perasaan penutur atau penulis secara tepat. Nilai rasa ini berkaitan dengan rasa sopan, halus, terhormat, bersih, kurang ajar, karas nista, jorok, dll. Ketepatan nilai rasa ini berkaitan erat dengan sopan santun. Contoh, kalimat bekas lurah di tempat saya menunaikan ibadah haji tidak efektif karena memiliki pilihan kata yang tidak tepat. Kata bekas tidak tepat nilai rasanya dalam konteks kalimat itu karena kata bekas bernilai kasar. Kata bekas cocok untuk mengungkapkan barangbarang yang sudah usang atau tidak terpakai. Kata bekas dalam kalimat itu 
menimbulkan kesan tidak sopan penutur kepada mitra tuturnya. Apabila penutur bermaksud baik-baik (tidak melecehkan mitra tuturnya), kata bekas dalam kalimat bekas lurah di tempat saya menunaikan ibadah haji adalah tidak tepat. Untuk menunjukkan kesetiakawanan, kalimat itu dapat diperbaiki menjadi mantan lurah di tempat saya menunaikan ibadah haji.

Kata yang tepat konteks adalah kata yang sesuai dengan konteks pemakaiannya, kontek pemakaiannya berkaitan dengan siapa yang diajak bicara, tempatnya di mana, suasananya bagaimana, waktunya kapan, sarananya apa, topiknya apa, dan ragam bahasanya apa. Contoh kalimat bapak-bapak dan ibu-ibu petani di kampung ini harus bisa menjastifikasi insektisida yang relevan dengan kondisi alam di sini, tidak efektif karena memiliki sejumlah kata yang tidak tepat konteks. Dalam kalimat itu, dapat diketahui bahwa konteks tuturan itu adalah para petani di kampung. Para petani di kampung umumnya pendidikannya rendah sehingga sulit memahami makna kata menjastifikasi, insektisida, relevan merupakan kata teknis yang kurang dipahami oleh para petani itu. Untuk mengefektifkan kalimat itu, kata-kata menjastifikasi, insektisida, relevan dapat diganti dengan kata yang umum di kalangan mereka, yaitu menentukan, racun serangga, cocok, sehingga menjadi bapak-bapak dan ibu-ibu petani hendaknya dapat menentukan racun hama yang cocok dengan keadaan alam di sini.

Ketepatan konteks juga dapat diukur berdasarkan kesesuaian pilihan kata dengan beragam bidang kegiatan. Ragam pemakaian bahaasa bermacam-macam jenisnya, tergantung dasar yang digunakan untuk mengelompokkan atas ragam sastra, ilmiah, dan komunikasi sehari-hari. Berdasarkan sarananya, ragam bahasa dapat dikelompokkan menjadi ragam lisan dan ragam tulis. Berdasarkan tingkat keresmiannya, bahasa dapat dikelompokkan menjadi regam resmi dan ragam tidak resmi. Ragam-ragam yang lain masih ada, tetapi ragam-ragam itu tidak disebutkan di sini. Contoh dalam ragam ilmiah, kalimat daerah yang hutannya gundul berpeluang besar dilanda banjir, apabila hujan turun mengguyur bumi tiada ampun tidak efektif dan tidak tepat konteks. Dalam ragam ilmiah, kata-kata, rasa, klausa, dan kalimat yang digunakan bermakna lugas dan akurat. Kalusa hujan turun mengguyur bumi tiada ampun tidak cocok untuk ragam ilmiah, karena klausa itu menggunakan gaya personifikasi yang maknanya kataforis. Kalimat itu 
dapat diefekifkan dengan mengganti klausa hujan turun mengguyur bumi tiada ampun menjadi hujan lebat, sehinggan membentuk daerah yang hutannya gundul berpeluang dilanda banjir apabila hujan lebat.

\section{Contoh Teks Prosedur}

\section{Cara Membuat Bubur Manado}

Menu sarapan super sehat dan kaya serat. Penambahan singkong dan ubi ungu, selain untuk memperkaya warna dan gizinya, juga membuat tekstur bubur beras merah ini lebih pulen.

Bahan-bahan yang digunakan antara lain:

1. 400 gram nasi merah

2. 200 gram singkong, cuci potong dadu.

3. 200 gram ubi ungu, cuci kupas, potong dadu

4. 2 batang sereh digeprek

5. 1 ikat kangkung, cuci, petik daunnya, rajang besar

6. 1 ikat bayam, cuci, petik daunnya

7. 1 buah jagung manis, dipipil

$8.1500 \mathrm{ml}$ air

Langkah-langkah pembuatan:

a. Didihkan air, masukkan berurutan nasi merah, singkong, ubi, jagung pipil, dan sereh. Aduk sampai bubur mengental.

b. Tambahkan kangkung dan bayam, aduk beberapa saat, jangan sampai terlalu layu.

c. Angkat dan hidangkan panas, ditemani ikan asin dan kerupuk.

Mudah, murah, dan sekaligus sehat. Sarapan sehat dengan menu makanan tradisional yang telah dikreasikan. Selamat mencoba!

(Sumber: Harsiati, Agus, dan E. Kosasih, 2016:98-99) 
Tabel 1

Struktur Teks Prosedur

\begin{tabular}{|c|c|}
\hline Struktur Teks & Kutipan \\
\hline 1 & 2 \\
\hline Tujuan & $\begin{array}{l}\text { Menu sarapan super sehat dan kaya serat. Penambahan } \\
\text { singkong dan ubi ungu, selain untuk memperkaya warna } \\
\text { dan gizinya, juga membuat tekstur bubur beras merah } \\
\text { ini lebih pulen. }\end{array}$ \\
\hline Bahan dan Alat & $\begin{array}{l}\text { Bahan-bahan yang digunakan antara lain: } \\
\text { 1. } 400 \text { gram nasi merah } \\
\text { 2. } 200 \text { gram singkong, cuci potong dadu. } \\
\text { 3. } 200 \text { gram ubi ungu, cuci kupas, potong dadu } \\
\text { 4. } 2 \text { batang sereh digeprek } \\
\text { 5. } 1 \text { ikat kangkung, cuci, petik daunnya, Rajang besar } \\
\text { 6. } 1 \text { ikat bayam, cuci, petik daunnya } \\
\text { 7. } 1 \text { buah jagung manis, dipipil } \\
\text { 8. } 1500 \text { ml air }\end{array}$ \\
\hline Langkah-langkah & $\begin{array}{l}\text { Langkah-langkah pembuatan: } \\
\text { a. Didihkan air, masukkan berurutan nasi merah, } \\
\text { singkong, ubi, jagung pipil, dan sereh. Aduk sampai } \\
\text { bubur mengental. } \\
\text { b. Tambahkan kangkung dan bayam, aduk beberapa } \\
\text { saat, jangan sampai terlalu layu. } \\
\text { c. Angkat dan hidangkan panas, ditemani ikan asin dan } \\
\text { kerupuk }\end{array}$ \\
\hline Penutup & $\begin{array}{l}\text { Mudah, murah, dan sekaligus sehat. Sarapan sehat } \\
\text { dengan menu makanan tradisional yang telah } \\
\text { dikreasikan. Selamat mencoba! }\end{array}$ \\
\hline
\end{tabular}

\section{B. Penelitian yang Relevan}

Sebelum penelitian ini dilaksanakan, telah pernah dilakukan penelitian 
terhadap masalah yang dikemukakan pada penelitian ini. Penelitian yang relevan tersebut dilakukan oleh Khairat dan Oktavia dan pada tahun 2017 serta Putri pada tahun 2018.

Khairat (2017) melakukan penelitian yang berjudul "Karakteristik Struktur dan Ciri Kebahasaan Teks Eksposisi Karya Mahasiswa PPBSI JBSI FBS UNP” Tujuan penelitian ini untuk mendeskripsikan karakteristik struktur dan ciri kebahasaan teks eksposisi karya mahasiswa PPBSI JBSI FBS UNP. Persamaan antara dua penelitian yaitu sama-sama menganalisis struktur dan ciri kebahasaan dalam sebuah teks. Perbedaan kedua penelitian ini adalah penelitian Khairat menganalisis karakteristik struktur dan ciri kebahasaan teks eksposisi karya mahasiswa, sedangkan penelitian ini menganalisis struktur dan ciri kebahasaan teks prosedur karya siswa.

Oktavia (2017) melakukan penelitian yang berjudul "Karakteristik Struktur dan Diksi Teks Cerpen Karya Siswa Kelas XI SMA Negeri 1 Suliki”. Tujuan penelitian ini untuk mendeskripsikan karakteristik struktur dan diksi teks cerpen karya siswa kelas XI SMA Negeri 1 Suliki. Persamaan antara dua penelitian ini yaitu sama-sama menganalisis struktur dan diksi dalam sebuah teks karya siswa. Perbedaan kedua penelitian ini adalah penelitian Oktaviani selain menganalisis karakteristik struktur juga menganalisis diksi, sedangkan penelitian ini menganalisis ciri kebahasaan teks disamping menganalisis karakteristik struktur. Teks yang dianalsis dalam kedua penelitian ini juga berbeda. Oktavia menganalisis teks cerpen, sedangkan penelitian ini menganalisis teks prosedur.

Putri (2018) melakukan penelitian yang berjudul "Struktur dan Kebahasaan Teks Cerita Fantasi Karya Siswa Kelas VII SMP Pembangunan Laboratorium UNP”. Tujuan penelitian ini untuk mendeskripsikan struktur dan kebahasaan yang terdapat dalam teks cerita fantasi karya siswa kelas VII SMP Pembangunan Laboratorium UNP. Persamaan antara dua penelitian ini sama-sama menganalisis struktur dan kebahasaan yang terdapat dalam sebuah teks. Perbedaan kedua penelitian ini adalah penelitian Putri meneliti kaidah kebahasaan pada bagian pronomina, konjungsi, kalimat langsung, dan tidak langsung. Penelitian ini meneliti kaidah kebahasaan pada konjungsi, kalimat imperatif, dan diksi. Perbedaan selanjutnya adalah lokasi penelitian Putri berada di SMP Pembangunan 
Laboratorium UNP, sedangkan penelitian ini berada di SMP Negeri 1 Kota Solok.

\section{Kerangka Konseptual}

Teks prosedur tulisan siswa perlu dianalisis. Analisis tersebut dikaitkan dengan struktur dan kebahasaan teks prosedur. Struktur merupakan unsur-unsur pembangun yang terdapat dalam sebuah teks. Struktur teks prosedur terdiri atas judul, tujuan, alat dan bahan, langkah-langkah, serta penutup. Kebahasaan teks prosedur yang akan dianalisis yaitu konjungsi dan diksi.

Dengan demikian, kerangka konseptual yang mendasari penelitian ini adalah sebagai berikut.

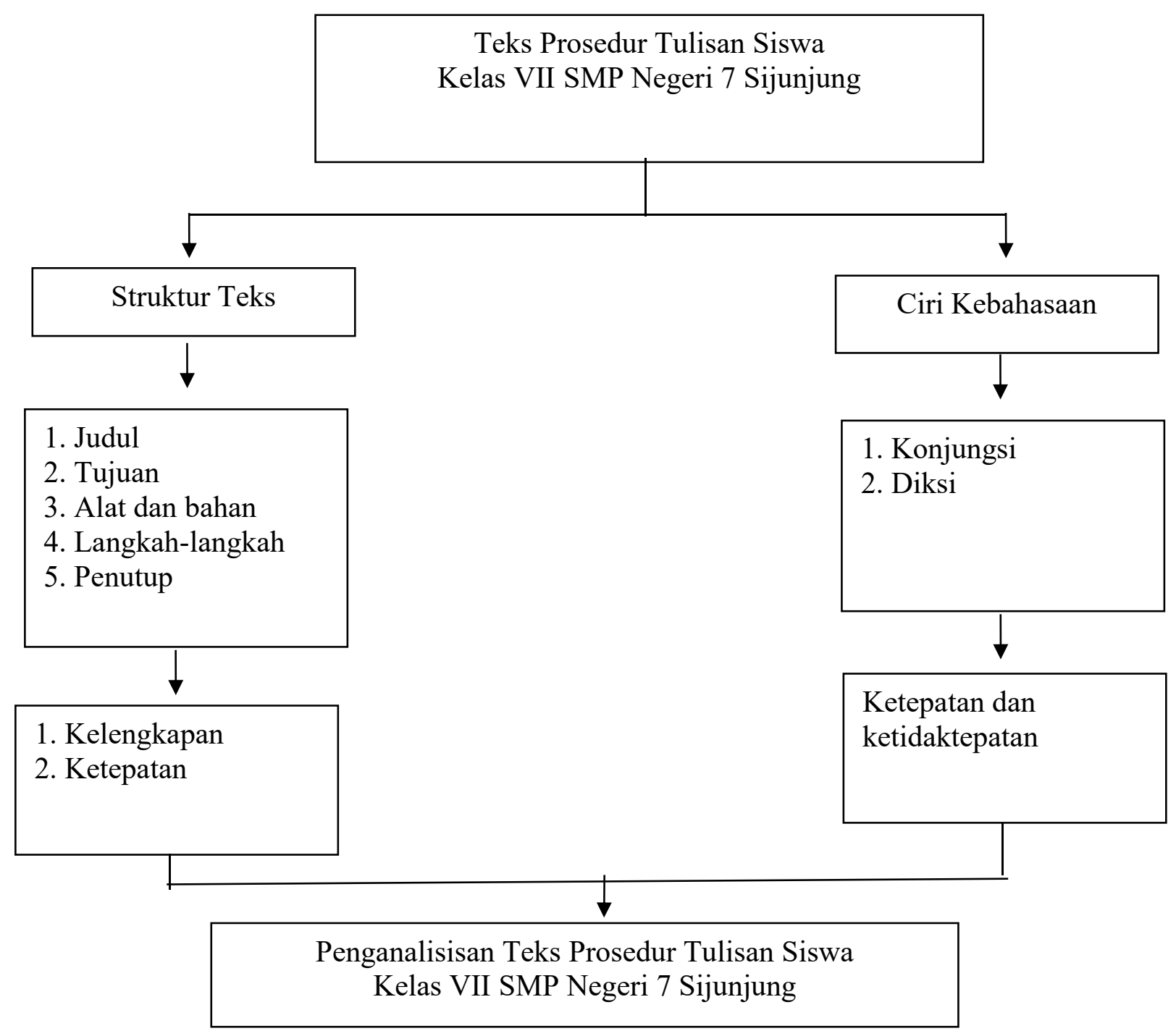

Gambar 2 Kerangka Konseptual 


\section{BAB III}

\section{METODOLOGI PENELITIAN}

\section{A. Jenis dan Metode Penelitian}

Jenis penelitian ini adalah penelitian kualitatif. Penelitian ini disebut penelitian kualitatif karena penelitian yang penganalisisannya menggunakan katakata. Menurut Moleong (2010:6), penelitian kualitatif adalah penelitian yang bermaksud untuk memahami fenomena tentang apa saja yang dialami oleh subjek penelitian dengan cara mendeskripsikan dalam bentuk kata-kata dan bahasa dengan metode ilmiah. Bodgan dan Taylor (dalam Moleong, 2015:4) juga menyatakan bahwa penelitian kualitatif adalah salah satu prosedur penelitian yang menganalisis deskriptif berupa ucapan atau tulisan dan perilaku orang-orang yang diamati. Sejalan dengan itu, Wahidmurni (2017) mengatakan penelitian kualitatif merupakan suatu cara yang digunakan untuk menjawab masalah penelitian yang berkaitan dengan data berupa narasi yang bersumber dari aktivitas wawancara, pengamatan, pengalian dokumen. Berdasarkan beberapa pendapat para ahli di atas, maka peneliti menggunakan pendapat Moleong (2010) pada jenis penelitian ini.

Metode yang digunakan dalam penelitian ini adalah metode deskriptif. Dikatakan dengan metode deskriptif karena penelitian ini mendeskripsikan struktur, diksi, dan konjungsi teks prosedur siswa kelas VII SMP Negeri 7 Sijunjung. Hal ini sesuai dengan pendapat Chaer (2011:9) yang menyatakan metode deskriptif adalah metode yang bertujuan untuk mendeskripsikan atau memaparkan proses dan hasil penelitian secara sistematik dan menekankan pada data faktual.

\section{B. Data dan Sumber Data}

Data dalam penelitian ini adalah struktur, diksi, dan konjungsi teks prosedur siswa kelas VII SMP Negeri 7 Sijunjung. Sumber data dalam penelitian ini adalah teks prosedur karya siswa kelas VII SMP Negeri 7 Sijunjung tahun ajaran 2021/2022. Teks tersebut berupa kumpulan tugas teks prosedur siswa SMP Negeri 7 Sijunjung yang dikumpulkan dan diarsipkan oleh guru bahasa Indonesia. Sumber data berjumlah tiga puluh teks prosedur yang ditulis oleh siswa SMP Negeri 7 Sijunjung. 


\section{Instrumen Penelitian}

Instrumen penelitian ini adalah peneliti sendiri. Hal tersebut sesuai dengan pendapat Sugiyono (2010:8) yang mengungkapkan bahwa dalam penelitian kualitatif yang menjadi instrumen atau alat penelitian adalah orang atau human instrument. yaitu peneliti sendiri. Peneliti meminjam teks prosedur yang ditulis oleh siswa kelas VII SMP Negeri 7 Sijunjung.

\section{Teknik Pengumpulan Data}

Teknik pengumpulan data dalam penelitian ini dilakukan melalui studi dokumentasi. Menurut Chaer (2011), pengumpulan data dihentikan apabila data telah memadai untuk bisa menjelaskan fokus kajian, atau menjawab pertanyaanpertanyaan kajian maka baru disusun suatu teori, suatu kaidah, atau suatu ketetapan. Penelitian ini mengumpulkan data dengan cara meminjam tugas siswa kelas VII SMP Negeri 7 Sijunjung berupa kumpulan teks prosedur kepada guru mata pelajaran bahasa Indonesia.

Pada penelitian ini, teknik pengumpulan dilakukan dengan tiga tahap, yaitu sebagai berikut. Pertama, membaca dan memahami teks prosedur siswa kelas VII SMP Negeri 7 Sijunjung. Hal ini dilakukan untuk memperoleh pemahaman yang jelas tentang isi teks yang akan diteliti. Kedua, menandai bagian-bagian yang berkaitan dengan struktur, diksi, dan konjungsi teks prosedur. Ketiga, menginventarisasi struktur, diksi dan konjungsi teks prosedur karya siswa kelas VII SMP Negeri 7 Sijunjung ke dalam format inventarisasi data.

\section{E. Teknik Pengabsahan Data}

Teknik terhadap keabsahan data pada dasarnya merupakan unsur yang tidak terpisahkan dari pengetahuan penelitian kualitatif. Keabsahan data dilakukan untuk membuktikan apakah penelitian yang dilakukan benar-benar merupakan penelitian ilmiah. Teknik pengabsahan data yang terdapat dalam penelitian ini adalah teknik triangulasi (crosS-check). Moleong (2010: 337-338) menyatakan bahwa teknik triangulasi adalah teknik keabsahan data yang memanfaatkan sesuatu yang lain di luar data untuk keperluan pengecekan data. Menurut Sugiyono (2010:330), triangulasi adalah teknik pengumpulan data yang bersifat 
menggabungkan data dari berbagai teknik pengumpulan data dan sumber yang telah ada. Keabsahan data dilakukan dengan memanfaatkan peneliti atau pengamat lain untuk keperluan pengecekan kembali data yang diperoleh. Pengamat yang akan mengecek data pada penelitian ini adalah Yetti Murni, S.Pd., selaku guru yang mengajar mata pelajaran bahasa Indonesia di kelas VII SMP Negeri 7 Sijunjung.

Maka dapat disimpulkan bahwa triangulasi adalah pengumpulan data dan pengecekan data dari sumber dengan berbagai cara. Berdasarkan beberapa pendapat para ahli di atas, maka peneliti menggunakan pendapat Moleong (2010) untuk teknik keabsahan data pada penelitian ini.

\section{F. Teknik Penganalisisan Data}

Setelah semua data terkumpul, dilakukan pemeriksaan dan analisis data. Data diperiksa dan dianalisis dengan langkah-langkah, sebagai berikut. Pertama, mengidentifikasi unsur umum data. Identifikasi unsur umum data dengan cara membuat format kode data dan judul teks. Kedua, mengidentifikasi data berdasarkan teori yang menjadi acuan. Identifikasi data dilakukan dengan cara membuat format identifikasi struktur, diksi dan konjungsi teks prosedur. Ketiga, menganalisis data. Menganalisis data dilakukan dengan cara membuat format analisis struktur teks prosedur, diksi dan konjungsi teks prosedur. Keempat, menginterpretasi data yang sudah dianalisis. Menginterpretasi data merupakan bentuk dari kegiatan untuk melakukan penggabungan terhadap sebuah hasil analisis yang telah dikumpulkan untuk mencari jawaban mengenai struktur, diksi dan konjungsi teks prosedur. Kelima, menyimpulkan hasil deskripsi data dengan menulis laporan. 


\section{DAFTAR PUSTAKA}

Agustina, Eka Sofia. 2017. Pembelajaran Bahasa Indonesia Berbasis Teks: Representasi Kurikulum 2013. Aksara Jurnal Bahasa dan Sastra. Vol. 18, No. 1, Hal. 84-99.

Atmazaki, Afnita, dan Farel Olva Zuve. 2017. Pengembangan Bahan Ajar Membaca Berbasis Konteks. Padang. Jurnal Pendidikan Bahasa dan Sastra Indonesia. 1(1).

Azura. 2014. "Kemampuan Menulis Teks Prosedur Siswa Kelas VII SMP Negeri 2 Percut Sei Tuan Tahun Pembelajaran 2017/2018”. Jurnal Sastra, Vol. 6 (1).118-119.

Chaer, Abdul. 2009. Sintaksis Bahasa Indonesia. Jakarta: Rineka Cipta.

Chaer, Abdul. 2011. Ragam Bahasa Ilmiah. Jakarta: Rineka Cipta.

Finoza, Lamuddin. 2010. Komposisi Bahasa Indonesia. Jakarta: Diksi.

Gafur, A dan Milaningrum. E 2015. Penulisan Teks Prosedur yang Dinilai Menggunakan Portofolio Kepada Mahasiswa Semester Empat pada Jurusan Tataboga di Politeknik Negeri Balikpapan. (Jurnal Sains Terapan, Nomor 2, Volume 1).

Harsiati, Agus, dan E. Kosasih. 2016. Bahasa Indonesia (Buku Ajar) SMP. Jakarta: Pusat Kurikulum dan perbukuan, Balitbang, Kemdikbud.

Kemendikbud. 2013. Bahasa Indonesia: Ekspresi Diri dan Akademik SMA/MA/SMK/MAK Kelas X. Jakarta: Kemendikbud.

Kemendikbud. 2014. Bahasa Indonesia: Ekspresi Diri dan Akademik SMAIMA/SMA/MAK Kelas X Edisi Revisi 2014. Jakarta: Kemendikbud.

Khairat, Hayatul. 2017. "Karakteristik Struktur dan Ciri Kebahasaan Teks Eksposisi Karya Mahasiswa PPBSI JBSI FBS UNP". Skripsi. Padang: FBS UNP.

Kridalaksana, Harimurti. 1990. Kelas Kata dalam Bahasa Indonesia. Jakarta: Kementrian Pendidikan dan Kebudayaan.

Kridalaksana, Harimurti. 2008. Kamus Linguistik. Jakarta: Gramedia Pustaka Utama.

Mahsun. 2014. Teks dalam Pembelajaran Bahasa Indonesia Kurikulum 2013. 
Jakarta: Raja Grafindo Persada.

Marahimin, Ismail. 2010. Menulis Secara Populer. Jakarta: Pustaka Jaya.

Moleong, Lexy. J. 2010. Metodologi Penelitian Kualitatif. Bandung: Remaja Rosdakarya.

Mulyadi, Y.A. 2014. Bahasa Indonesia untuk Siswa SMP/Mts Kelas V. Bandung: Yrama Widya.

Mustika, Nursaid, dan Ena, R. 2018. "Struktur, Diksi, dan Kalimat Teks Cerita Fantasi Karya Siswa Kelas VII SMP Negeri 27 Padang”. Jurnal Pendidikan Bahasa dan Sastra Indonesia, Vol. 3, No.7.

Ngusman, Abdul Manaf. 2010. Semantik Bahasa Indonesia. Padang: UNP Press.

Oktavia, Harisa Yeri. 2017. "Karakteristik Struktur dan Diksi Teks Cerpen Karya Siswa Kelas XI SMA Negeri 1 Suliki". Skripsi. Padang: FBS UNP.

Priyatni, Endah Tri. 2014. Desain Pembelajaran Bahasa Indonesia dalam Kurikuium 2013. Jakarta: Cahaya Prima Sentosa.

Putrayasa, lda Bagus. 2010. Kalimat Efektif (Diksi, Struktur, dan Logika). Bandung: Refika Aditama.

Putri, Finny Rizkiah. 2018. "Struktur dan Kebahasaan Teks Cerita Fantasi Karya Siswa Kelas VIl SMP Pembangunan Laboratorium UNP", Skripsi. Padang: FBS UNP.

Rahardi, K. 2009. Bahasa Indonesia untuk Perguruan Tinggi. Jakarta: Erlangga. Ramlan. 1991. Morfologi. Yogyakarta: Karyono.

Simanjuntak, Nurmina, Harris, E.T., dan Afnita. 2018. Hubungan Keterampilan Membaca Pemahaman dengan Keterampilan Menulis Teks Deskripsi Siswa Kelas VII SMP Negeri 7 Padang. Jurnal Pendidikan Bahasa dan Sastra Indonesia. 7(3) Seri D 249-256.

Sugiyono. 2010. Metode Penelitian Kuantitatif, Kualitatif, dan R\&D. Bandung: Alfabeta.

Thahar. H. E. 2008. Menulis Kreatif. Padang: UNP Press.

Ulfa, Wildani. 2019. Struktur dan Kebahasaan Teks Prosedur Siswa Kelas VII SMP Negeri 1 Kota Solok (Skripsi). Padang: FBS UNP.

Utami, dkk. 2019. "Pengaruh Teknik Pemodelan terhadap Keterampilan MenulisTeks Prosedur Siswa Kelas XI SMK Negeri 1 Tapan”. Jurnal 
Pendidikan Bahasa dan Sastra Indonesia, Vol. 8, No.1.

Wahidmurni. 2017. Pemaparan Metode Penelitian Kualitatif. (Artikel Imiah). Diunduh tanggal 13 November 2021. 